\title{
Propuesta de dos principios
}

Pistan

OLIANTEA es un término castizo que, según el diccionario de la lengua española de la Real Academia Española, significa "Colección o agregado de noticias en materias diferentes y de distinta clase", y proviene de una palabra griega que quiere decir "de muchas flores".

Con este sugestivo nombre, después de muchas cavilaciones, nace POLIANTEA, la Revista Académica y Cultural de la Fundación Politécnico Grancolombiano, Institución Universitaria.

Tales meditaciones surgieron de la gran prevención que existe respecto de las revistas universitarias en nuestro medio, por razones tan valederas como las siguientes:

- Que son costosas y es muy difícil su autosostenimiento económico.

- Que tienen bajo contenido investigativo.

- Que en un medio pobre como el nuestro, caracterizado por instituciones de educación superior especializadas en la formación profesional, más que puramente académica, ninguna revista universitaria ha logrado abarcar un espacio cultural amplio.

- Que tienen poca circulación y difusión, por lo cual existen demasiadas revistas intrascendentes.

- Que no expresan adecuadamente el espíritu de las instituciones a las que pertenecen.

- Que son revistas de variedades, que no tienen una política editorial definida, ni logran profundizar en temas o especialidades específicos.

- Etc, etc...

Yo he compartido estos argumentos, en general, y me tortura permanentemente la conclusión a que he llegado, de que un país de cierto desarrollo cultural como Colombia no ha tenido sino una revista autónoma, no universitaria, con éxito económico, basada en el impulso periodístico de una sola persona.

Sin embargo, en esta Fundación hemos sentido urgente necesidad de contar con un medio de expresión de múltiples manifestaciones culturales y académicas de la propia comunidad universitaria, y que nos sirva también para promover ilimitadamente nuestro bagaje cultural. 
Por esta razón damos a luz esta publicación al servicio no sólo de la Institución sino de la comunidad en general, dejando de lado los aspectos negativos que reseñé anteriormente.

La Revista tendrá en principio una frecuencia semestral, pero con posibilidades de aumento a medida que se vaya requiriendo. Creo que desde esta primera edición ya va logrando un contenido interesante y una presentación física agradable y atractiva, gracias al trabajo y al esfuerzo de su Director, Sebastián Romero Buj, y del Departamento de Comunicaciones y Editorial de la Institución. Desde antes de su nacimiento, POLIANTEA ha tenido el privilegio de contar con el concurso generoso, desprendido y eficaz de Juan Gustavo Cobo Borda, como Asesor Editorial, en quien reconozco a una persona especialmente bondadosa y poseedora de una de las mayores culturas literarias de nuestro país.

A mi juicio, la característica esencial de una revista universitaria debe ser la independencia con respecto a cualquier credo religioso, ideología política o interés económico, aunque esto le dificulte trascender, pues de lo contrario no haría honor al concepto de universidad, que viene de universo, y perdería la oportunidad de reflejar con credibilidad las valiosas contribuciones que pueden hacer todas las tendencias ideológicas. Yo encuentro que las religiones y las ideologías políticas por lo general se basan en dogmas que han opacado sus respectivas aportaciones culturales y han contribuido a los grandes sinsentidos, tragedias y exabruptos de la historia humana, en un mundo en el que no hay nada absoluto, caracterizado por la incertidumbre, y en el que la filosofía no pasa de ser el intento de explicar las cuestiones que nunca tendrán respuesta definitiva.

En este orden de ideas, en medio de una vida intensa y tortuosa, en la cual me han tocado las situaciones más extraordinarias, yo no me atrevo a proponer sino dos principios como inspiradores de esta Revista:

1. El espíritu de bondad y de amor al prójimo, que, para no limitarlo a una connotación religiosa, prefiero denominarlo sentido de solidaridad, generosidad y equidad, pues yo concreté mi vida espiritual exclusivamente a este principio, y no soy una persona religiosa, ni pertenezco a ninguna religión, aunque las respeto a todas. Si digo que no pertenezco a ninguna religión en particular, es porque me siento más bien perteneciente al fundamento esencial de todas ellas, que es precisamente el sentido de solidaridad. Podría decirse que de alguna manera este principio engloba todos los demás altos valores de la humanidad. Según el novelista inglés William Sommerset Maugham, en su bella novela titulada El Filo de la Navaja, puede ser la fuerza espiritual más poderosa del ser humano.

2. La libertad, como facultad o atributo indispensable para la realización del ser humano, pero, obviamente, limitada por la libertad igualitaria de todos los seres humanos, dentro de lo que se podría llamar un liberalismo social.

Creo que estos son dos de los pocos principios que podrían reunir el consenso general de la cultura humana actual, aunque su trascendencia práctica sea tan escasa. 
Dentro de estos principios, quisiera que la Revista POLIANTEA cumpla los siguientes propósitos fundamentales:

- Servir como órgano de expresión de las diversas manifestaciones culturales y académicas de nuestra comunidad universitaria.

- Estimular el espíritu investigativo de nuestros estudiantes, profesores y egresados, para contribuir a la solución de problemas de la sociedad humana en todos sus ámbitos.

- Acoger manifestaciones del entorno local, nacional, mundial y universal que contribuyan a la misma solución de problemas y a engrandecer nuestro bagaje cultural.

- Mantener actualizada a la comunidad universitaria, incluyendo a los ex alumnos, respecto del desarrollo cultural y académico del país y del mundo.

- Reflejar el espíritu amable y el sano ambiente que caracterizan a la Institución.

- Ir derrotando poco a poco el paradigma de que un medio de comunicación universitario no puede alcanzar una influencia cultural importante en nuestro medio.

- Autosostenerse desde el punto de vista económico, sin perder su independencia editorial.

- Ganarse su permanencia en el medio cultural.

- Profundizar en los temas empresariales que constituyen la especialidad académica de la Institución.

En el ámbito académico de inicios del tercer milenio de la era cristiana se ha puesto muy en boga el concepto o fenómeno mundial de Globalización, como pretexto para tratar de entender y encontrar soluciones a los gravísimos problemas del mundo infeliz, contradictorio y desequilibrado en que ha vivido la humanidad desde sus orígenes; un mundo que pareciera inviable, por no poder demostrar su capacidad de sostener a los 6.000 millones de habitantes que tiene actualmente, y mucho menos a los 9.000 millones que tendrá en el año 2050. Es un mundo que adolece de contradicciones tan fundamentales como la de que la privilegiada capacidad de razonar del ser humano no le ha servido solamente para lograr un increíble desarrollo científico, tecnológico y cultural, sino para caracterizarse como la especie carnívora más perversa del planeta Tierra, quizás la única capaz de ejercer la violencia no sólo contra casi todas las demás sino contra sí misma, y de destruir hasta su propio medio ambiente. Precisamente hace unos pocos meses, en un prólogo para un libro sobre Globalización y Derecho que publicamos, traté de reflexionar sobre las graves contradicciones de la historia humana en los campos jurídico, político, económico y cultural, y me aventuré a calificar la Globalización como un proceso que se está desarrollando en forma "entre silvestre y agreste".

Con el objeto de contribuir al estudio de la Globalización, POLIANTEA tendrá una separata permanente, incorporada a la Revista, que será publicada bajo la responsabilidad conjunta de la Corporación Escenarios, entidad presidida por el ex presidente de la República de Colombia Ernesto Samper Pizano, y de la Fundación Politécnico Gran- 
colombiano, Institución Universitaria. Esta sección también tendrá un carácter estrictamente académico y cultural e, igualmente, será independiente e imparcial desde los puntos de vista ideológico y político.

La principal fuente de material académico de la separata será la alianza para el estudio de la Globalización que establecimos hace aproximadamente dos años entre la Universidad de Salamanca, la propia Corporación Escenarios y esta Fundación, en desarrollo de la cual ya se han llevado a cabo múltiples seminarios, foros y publicaciones, bajo las orientaciones de un Comité Asesor que se reúne frecuente y continuamente.

Debido a varios de los conceptos que he emitido en este Editorial, algunas personas me tachan de pesimista y consideran que todo educador debe ser optimista por excelencia. Yo, por el contrario, pienso que el deber del educador es ser realista e intentar enseñarles a sus estudiantes a vivir "con los pies sobre la Tierra", no "sobre las nubes", sin perjuicio de brindarles esperanza. Nunca he podido congeniar con el optimismo irracional.

Pablo Michelsen Niño

Rector 